\section{Mesterlig om hjernen}

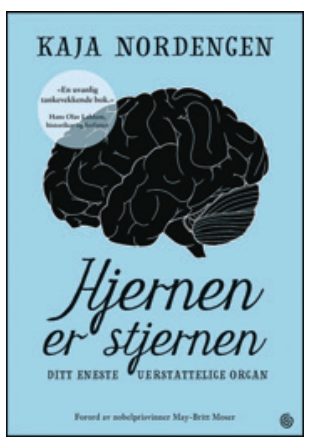

Kaja Nordengen

Hjernen er stjernen

Ditt eneste uerstattelige organ. 208 s, ill.

Oslo: Kagge Forlag, 2016. Pris NOK 399

ISBN 978-82-489-1877-6

Hjerneforskningen avdekker stadig flere av hjernens store og små mysterier. Men jo mer kunnskap vi får om nevroner, støtteceller, synapser og nevrotransmittere, desto mer komplekst viser dette drøyt kilotunge organet seg å være. Hjernen styrer alle funksjoner i kroppen og gjør oss alle til unike individer. En frisk og aktiv hjerne er en viktig forutsetning for et godt liv. For å ta vare på hjernen bør vi alle kjenne noe til hvordan den fungerer og hvordan den kan bevares best mulig opp i høy alder. Hjerneforskningen er imidlertid av natur ofte reduksjonistisk og vanskelig tilgjengelig. God forskningsformidling og popularisering om hjernen er derfor en spesielt viktig oppgave.

Forfatteren av Hjernen er stjernen er en lege som på tross av sin unge alder allerede har skaffet seg bred erfaring både som hjerneforsker og kliniker. Hennes forskningsarena har vært laboratoriet og de mange små detaljene. Med denne utgivelsen viser hun imidlertid at hun også mestrer det å ta med lesere uten spesiell forhåndskunnskap inn i hjernens indre på en spennende, morsom og ikke minst lærerik måte.

Ved hjelp av enkle, illustrative tegninger, laget av forfatterens søster(!), fremstilles hjernens anatomi og funksjon på en forståelig måte. Leseren blir raskt kjent med basalgangliene, thalamus, lillehjernen og ikke minst prefrontal hjernebark. Med vekt på sentrale og spennende emner som evolusjon, hukommelse, personlighet samt steds- og retningssans forklares både basal hjernefysiologi og nyere hjerneforskning på en pedagogisk fin måte. Når fenomener som kjærlighet, mat, rus og avhengighet introduseres, skjer dette i samarbeid med de for de fleste leseres del sammen med «nye venner» som dopamin, serotonin og acetylkolin. Leseren vil forhåpentligvis under leseprosessen oppleve at boken virkelig angår en selv og sitt eget liv.

Språket flyter lett, og teksten burde være greit lesbar for de aller fleste. Forfatteren går ikke av veien for å bruke eksempler fra sin egen oppvekst og sitt eget voksenliv, noe som gjør at boken også får et personlig preg. Den har en gjennomgående god faglig forankring, og hvert kapittel har sentrale litteraturreferanser. Bakerst finnes dessuten et nyttig stikkordregister.

Hjernen er stjernen er forskningsformidling av ypperste klasse.

\section{Christian Georg Lund}

Spesialist i nevrologi, Nevrologisk avdeling

Oslo universitetssykehus, Rikshospitalet

\section{Den døende pasienten - en investering verd?}

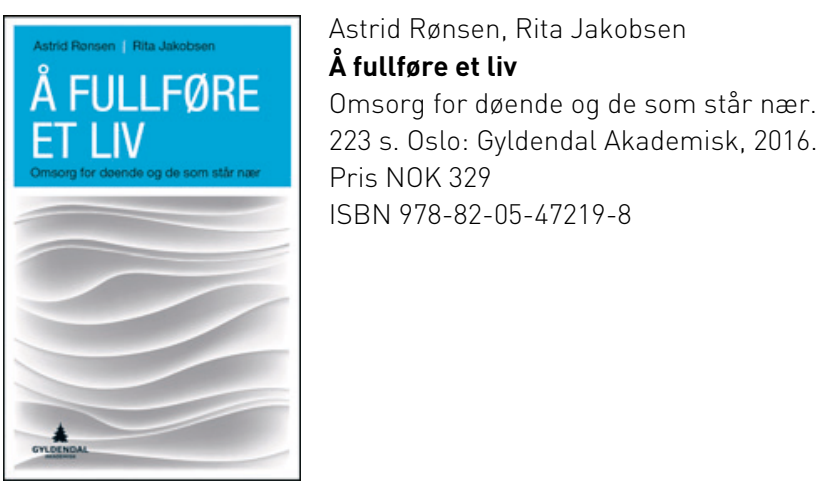

A fullføre et liv dreier seg om palliativ omsorg på pasientens og familiens premisser. Forfatterne bruker fortellingens kraft som læringsbasis for økt innsikt i møter med mennesker i siste del av livet. Gjennom flere fortellinger møter vi pasienter, pårørende og hjelpere i krevende situasjoner. Den narrative tilnærmingen bidrar til visualisering av og nærhet til temaet. Derigjennom synliggjøres nødvendigheten av at hjelperen blir berørt av pasienten og dennes situasjon for å kunne gjøre en god jobb. Siste del vies spørsmål omkring organisering av omsorgen for alvorlig syke og døende i Norge sammenlignet med i andre land.

Formen er sakprosa, og forfatterne beskriver en tilsynelatende og erkjentlig virkeligheten i fortellings form. De påfølgende analysene av fortellingene fungerer som læringsbudskap med tette henvisninger til annen litteratur til støtte for egne betraktninger. Boken krever mye av leseren konsentrasjonsmessig. I tillegg er den krevende emosjonelt, idet leseren må forholde seg inngående til sårbarheten og smerten som beskrives. Dessverre skjemmes den av forstyrrende skrivefeil - både manglende ord og ortografiske feil. Det er synd, for forfatterne mestrer fortellingens kunst meget godt, og budskapet er viktig.

Medisinske betraktninger og medikamentell behandling er ikke tema. Det er hjelperen som terapeutisk middel som står sentralt. For en palliativmedisiner kan dette fremstå som noe amputert. Men samtidig gir nettopp dette tyngde til betydningen av personlig engasjement og investering i pasienten, helt sentrale elementer vi kan frykte kan komme til å mangle under vår tids vektlegging av dokumentasjon og prosedyre. Slik sett er dette frydefull lesning, om enn krevende. Å fullføre et liv innehar også originalitet i det at leseren forhåpentlig blir «vekket» til å se på vanlige hendelser med nye øyne.

Astrid Rønsen og Rita Jakobsen er henholdsvis sykepleier/førstelektor og førsteamanuensis med lang fartstid i palliativt arbeid og utdanning. Astrid Rønsen er også leder for stiftelsen Hospiceforum Norge. Dette gjenspeiles i siste del, som dreier seg om organisering av palliativt arbeid her i landet. Synspunktene her er preget av hennes posisjon som leder for stiftelsen og kunne godt vært mer nyansert, som sakprosa betraktet.

Forfatterne har ønsket å sette ord på ulike utfordringer omsorgsutøvere i palliasjon kan komme til å møte samt gi et innblikk i situasjonsforståelse og atferd. Dette synes jeg de har lyktes godt med. A fullføre et liv er aktuell for alle som arbeider med mennesker i siste fase av livet. I tillegg bør den leses med ettertenksomhet av studenter i medisin, sykepleie og andre helse- og sosialfag og deres lærere.

Siri Hagen Brelin

Overlege, Kreftavdeling

Sykehuset Østfold

Fredrikstad 